\title{
Deoxynivalenol in the wheat milling process and wheat-based products and daily intake estimates for the Southern Brazilian population
}

\author{
Geovana D. Savi ${ }^{a, *}$, Karim C. Piacentini ${ }^{a}$, Casiane S. Tibola ${ }^{b}$, Karolina Santos ${ }^{\text {a }}$, \\ Giovana Sousa Maria ${ }^{a}$, Vildes M. Scussel ${ }^{a}$ \\ a Laboratory of Mycotoxicology and Food Contaminants, Food Science and Technology Department, Center of Agricultural Sciences, Federal University of \\ Santa Catarina, Florianopolis, SC, Brazil \\ ${ }^{\mathrm{b}}$ Brazilian Agricultural Research Corporation, EMBRAPA Wheat, Passo Fundo, RS, Brazil
}

\section{A R T I C L E I N F O}

\section{Article history:}

Received 10 August 2015

Received in revised form 30 September

2015

Accepted 24 October 2015

Available online 28 October 2015

\section{Keywords:}

Milled wheat

Finished flour

Bran

Wheat products

Mycotoxin distribution

Regulation

Daily consumption

Chemical compounds studied in this article:

Deoxynivalenol (PubChem CID:40024)

\begin{abstract}
A B S T R A C T
Fusarium head blight of wheat is caused by the Fusarium species that produces mycotoxins, such as deoxynivalenol (DON). The distribution of DON in wheat products can lead to high economic and health impacts. The objective of this study was to evaluate the natural distribution of DON in the wheat milling process and wheat-based products, as well as the daily intake estimates for the Southern Brazilian population. The fractions of wheat grains (milled wheat, finished flour and bran) were produced in a mill. Additionally, wheat-derived products, such as pasta, bread and crackers were analyzed. The bran fraction had the highest mean concentration of DON $(2278 \mu \mathrm{g} \mathrm{kg}-1)$, followed by milled wheat and finished flour (1895 $\mu \mathrm{g} \mathrm{kg}^{-1}$ and $1305 \mu \mathrm{g} \mathrm{kg}-1$ ). The distribution factor in the finished flour (69\%) fraction demonstrates that DON was reduced when compared to milled wheat, by contrast of bran fraction that presents higher DON levels (120\%). A percentage of 35\% bran, 35\% finished flour and 30\% milled wheat samples would not be in compliance with future Brazilian regulations for DON levels. From the wheat-based products analyzed, $17 \%$ of whole bread and $10 \%$ of salted cracker products were contaminated with DON, with a median of $437 \mu \mathrm{g} \mathrm{kg}^{-1}$ and $624 \mu \mathrm{g} \mathrm{kg}^{-1}$, respectively. The finished flour was the fraction that most contributes to the daily intake of DON in Southern Brazil, representing $89.6 \%$ of the provisional maximum tolerable daily intake.
\end{abstract}

(c) 2015 Elsevier Ltd. All rights reserved.

\section{Introduction}

Fusarium head blight (FHB) caused by different species of Fusarium, is a serious worldwide problem in wheat grains. This disease causes agricultural damage by reducing harvest yield due to poor grain quality and affects processed products from infected grains (Parry, Jenkinson, \& Mcleod, 1995; Savi et al., 2015; Scussel, Beber, \& Tonon, 2011). Moreover, it presents a threat to food safety because of the accumulation of mycotoxins in wheat grains and their products, especially deoxynivalenol (DON), considered to be the most important wheat hazard (McMullen, Jones, \& Gallenberg, 1997). The accumulation of DON in human and animal bodies

\footnotetext{
* Corresponding author. LABMICO, Food Science and Technology Department Centre of Agricultural Sciences, Federal University of Santa Catarina, Rod. Admar Gonzaga, Itacorubi, 1346, Florianopolis, SC, Brazil.

E-mail address: geovanasavi@hotmail.com.br (G.D. Savi).
}

after ingestion of contaminated food can induce development of acute and chronic effects, such as immunosuppression, neurotoxicity, embryotoxicity and teratogenicity (Pestka, 2007; Rotter, Prelusky, \& Pestka, 1996; Wijnands \& Van Leusden, 2000).

The toxicity of DON has led many countries to set up regulations for its control in wheat grains and their products intended for human or animal consumption. In Brazil, the maximum limits established in 2012 for milled wheat, whole flour and wheat bran were $2000 \mu \mathrm{g} \mathrm{kg}^{-1}$ and for wheat flour, pasta, crackers and biscuits were $1750 \mu \mathrm{g} \mathrm{kg}^{-1}$ (ANVISA, 2011). These levels will be progressively reduced and in 2017 will be set at $1000 \mu \mathrm{g} \mathrm{kg}^{-1}$ and $750 \mu \mathrm{g} \mathrm{kg}^{-1}$ for the products stated above, respectively (ANVISA, 2013). For unprocessed wheat grain, the maximum limit will be set at $3000 \mu \mathrm{g} \mathrm{kg}^{-1}$ in 2017 (ANVISA, 2013). It is necessary to mention that no regulation limits have been established for animal feed in Brazil. Nowadays, the European Commission has established the limit of DON equal to $1250 \mu \mathrm{g} \mathrm{kg}-1$ for unprocessed cereals and 
$1750 \mu \mathrm{g} \mathrm{kg}^{-1}$ for unprocessed durum wheat (EC, 2006; 2007). For cereals intended for direct human consumption, cereal flour, bran and germ as end products marketed for direct human consumption as well as pasta (dry), the limit of DON is $750 \mu \mathrm{g} \mathrm{kg}-1$. In addition, bread (including small bakery wares), pastries, biscuits, cereal snacks and breakfast cereals are equal to $500 \mu \mathrm{g} \mathrm{kg}^{-1}$.

Most of the wheat harvested in the world is subjected to milling, the procedure by which whole wheat grains are ground and their components separated into milled fractions based on particle size. However, the wheat does not have tissue structures within the kernel to act as an effective barrier against fungal invasion and the subsequent synthesis of mycotoxins and the entire milling fraction could be contaminated as a result (Pinson-Gadais et al., 2007).

The natural occurrence of DON in wheat and its products has been reported worldwide, including in Brazil (Bensassi, Zaied, Abid, Hajlaoui, \& Bacha, 2010; Mishra, Ansari, Dwivedi, Pandey, \& Das, 2013; Santos et al., 2013; Savi, Piacentini, Tibola, \& Scussel, 2014). Moreover, DON can be resistant to the wheat milling process and remain in by-products such as spaghetti (Visconti, Haidukowski, Pascale, \& Silvestri, 2004), wheat flour and bran (Rodrigues \& Naehrer, 2012; Tibola, Fernandes, Guarienti, \& Nicolau, 2015), wheat germ and wheat germ oil (Giménez et al., 2013) and bread (Pacin, Ciancio Bovier, Cano, Taglieri, \& Hernandez Pezzani, 2010; Zhang \& Wang, 2014).

The distribution of DON in wheat fractions and their products can enter in the food chain of animals and humans directly and negatively impact the economy and health. In addition, the distribution of the wheat milling fractions, usually intended for animal feed such as bran, may also present useful support in the future consideration of the legal maximum limit (Tibola et al., 2015). Therefore, the objective of this study was to evaluate the natural distribution of DON in the wheat milling process and in wheatbased products, as well as daily intake estimates for the Southern Brazilian population.

\section{Materials and methods}

\subsection{Sample characterization}

Wheat grain samples from different cultivars harvested during the 2014 crop season from Southern Brazil were used. Wheat grains were cleaned and dried in the storage units. The milling process of samples was performed by Embrapa Wheat (Brazilian Agricultural Research Corporation). Each sample (1000 g) was milled in the Laboratory Mill $3100^{\circledR}$ (Perten, Sweden), to obtain the milled wheat fraction. The same set of samples, composed of $5000 \mathrm{~g}$, were conditioned to a $14 \%$ moisture content and milled using a pilot-scale mill Quadrumat Senior ${ }^{\circledR}$ (Brabender, Germany), with a standard setting for hard wheat (AACC, 2000). This milling process produced the following fractions: milled wheat, finished flour (reduction and break flour) and bran (the outer layers of wheat kernel). The milled wheat, finished flour and bran were weighed and mixed separately, before the division of $200 \mathrm{~g}$ each sample for mycotoxin analysis (60 samples). Samples were packed in polyethylene bags and stored at $8{ }^{\circ} \mathrm{C}$ for DON analysis in the Laboratory of Mycotoxicology and Food Contaminants, Food Science and Technology Department, Center of Agricultural Sciences at the Federal University of Santa Catarina, Brazil. Additionally, wheat-based products, such as pasta of type semolina, eggs and common pasta, sweet common and whole bread and sweet and salted crackers, were purchased from the local retail market in the same period. The products were weighed (200 g each sample) and mixed separately for mycotoxin analysis (30 samples per group, totaling 90 samples).

\subsection{Chemicals and reagents}

DON standards were supplied by Sigma Aldrich Chemicals (St Louis, MO, USA). The solutions were prepared in acetonitrile at a concentration of $1 \mathrm{mg} \mathrm{mL}^{-1}$ and stored at $-20{ }^{\circ} \mathrm{C}$ until use. Working standard solutions, ranging from 0.15 to $10 \mu \mathrm{g} \mathrm{mL}^{-1}$, were prepared from suitable dilutions of the stock solution in the mobile phase acetonitrile:water $(10: 90, \mathrm{v} / \mathrm{v})$ and stored at $4{ }^{\circ} \mathrm{C}$. The solvents acetonitrile and methanol were obtained from Vetec (Duque de Caxias, RJ, Brazil) at LC grade. Water was obtained from a MilliQ system on $18.2 \mathrm{M} \Omega / \mathrm{cm}$ (Millipore, Bedford, MA, USA). For the sample clean-up step, an immunoaffinity column of DON-Test (Vicam, Milford, MA, USA) was used according to the manufacturer procedures.

\subsection{DON determination}

Milled wheat samples were analyzed using the immunoaffinity columns for the cleaning step, according to the Vicam protocol DON Test, $N_{0}$ G1005 USA (Vicam, 2013), with some modifications. In summary, $25 \mathrm{~g}$ of each sample was ground in an industrial blender jar with $100 \mathrm{~mL}$ of LC grade water. The mixture was blended for $30 \mathrm{~s}$, followed twice by filtration and cleaning using the immunoaffinity column (DON Test HPLC). This column was first conditioned with $1 \mathrm{~mL}$ of LC grade water and the filtrate sample $(1 \mathrm{~mL})$ was then loaded in a flow rate of one drop per second. After washing the column with $2.5 \mathrm{~mL}$ of LC grade water, the toxin was slowly eluted with $2 \mathrm{~mL}$ of $100 \%$ LC grade methanol. The eluate was evaporated using a heating block device at $40{ }^{\circ} \mathrm{C}$ with a gentle nitrogen stream and the dry residue was redissolved in $200 \mu \mathrm{L}$ of mobile phase acetonitrile:water (10:90, v/v).

\subsection{HPLC-DAD analysis}

The determination of DON levels was carried out by high performance liquid chromatography (HPLC), a Shimadzu (Kyoto, Japan), equipped with an isocratic pump (LC-20AT), column oven (CTO-20A), prominence communication bus module (CBM-20A), degasser (DGU-20A), autosampler (SIL-20A) and a detector diode array (DAD) (SPD-M 20A). Chromatographic separations were performed on a C18 reversed-phase column $(250 \times 4.6 \mathrm{~mm}, 4 \mu)$, Synergi Fusion-RP 80A (Phenomenex, Torrance, USA). The column temperature was maintained at $30^{\circ} \mathrm{C}$. The isocratic mobile phase consisted of acetonitrile:water $(10: 90, \mathrm{v} / \mathrm{v})$. The retention time of DON was approximately $12.2 \pm 0.5 \mathrm{~min}$. The extract $(20 \mu \mathrm{L})$ was injected into the LC/DAD/UV System set at a wavelength equal to $218 \mathrm{~nm}$ and the mobile phase was delivered in a constant flow rate of $1 \mathrm{~mL} \mathrm{~min}{ }^{-1}$. Quantification of DON levels was performed by measurement of the peak area at DON retention time compared with the standard solutions used for the calibration curve.

\subsection{Validation of analytical method}

Validation of the analytical method was based on the criteria of linearity, selectivity, sensitivity, reproducibility, limit of detection (LOD) and quantification (LOQ), and recovery. The linearity of the method was confirmed using the calibration curve. The calibration curves were constructed with different DON concentrations from 0.15 to $10 \mu \mathrm{g} \mathrm{mL}^{-1}$. Linearity was shown with the correlation coefficient $\left(R^{2}\right)$ through linear regression analysis. The selectivity of the method was determined through the comparative analysis of non-spiked blank wheat samples and spiked wheat samples at 250, 1000 and $1500 \mu \mathrm{g} \mathrm{kg}^{-1}$ of DON. The sensitivity of the method was assessed using the LOD (signal-to-noise - S/N ratios of $1 / 3$ ) and LOQ (S/N 1/10). The recovery process was set by spiking DONfree samples of wheat with DON concentrations of 250, 1000 and 
$1500 \mu \mathrm{g} \mathrm{kg}^{-1}$ (letting the samples stand for at least $2 \mathrm{~h}$ ) on the same HPLC conditions.

\subsection{Estimate of the average probable daily intake and maximum probable daily intake}

The Average Probable Daily Intake (APDI) and Maximum Probable Daily Intake (MPDI) were calculated using the average levels of DON and the maximum concentrations found in the samples, which were multiplied by the daily consumption of wheat-based food in the Southern Brazil using data from the Brazilian Institute of Geography and Statistics - IBGE (2011) and divided by $60 \mathrm{~kg}$ of body weight (Herrman \& Yunes, 1999; Zimmer et al., 2008 and Martins et al., 2012). The Provisional Maximum Tolerable Daily Intake (PMTDI) calculation was based on tolerable intake $1 \mu \mathrm{g} \mathrm{kg}^{-1}$ body weight day ${ }^{-1}$ for DON and its acetylated derivatives (JECFA, 2011).

\subsection{Statistical analysis}

Results regarding DON in wheat milling fractions were reported as the mean, median and 90 th percentile. The parameter Distribution Factor was adopted to express the overall reduction or increase in DON content in each milled fraction compared to their respective contents measured in milled wheat (Cheli et al., 2010). Analysis of variance (ANOVA) and Tukey's Multiple Comparison Test were first performed to evaluate the differences between concentrations of DON found in wheat milling fractions with a probability value of $P<0.05$ to determine the statistical significance. Finally, analysis of variance (ANOVA) and Bonferroni Post-Test to evaluate the differences between DON levels $\left(\mu \mathrm{g} \mathrm{kg}^{-1}\right)$ in the finished flour and bran fractions when compared with milled wheat of the positive samples were analyzed individually.

\section{Results and discussion}

\subsection{Method validation}

According to the linear regression analysis, calibration curves for DON were linear from 0.15 to $10 \mu \mathrm{g} \mathrm{mL}-1$, which showed correlation $\mathrm{R}^{2}$ of 0.999 . The LOD $(1 / 3)$ was $22 \mu \mathrm{g} \mathrm{kg}-1$, and the LOQ $(1 / 10)$ was $77 \mu \mathrm{g} \mathrm{kg}-1$. The mean recoveries were $87 \pm 9 \%$, $96 \pm 6 \%$ and $93 \pm 3 \%$ in the spiked wheat samples (in triplicates) at 250,1000 and $1500 \mu \mathrm{g} \mathrm{kg}-1$, respectively. These results suggest that the chosen analytical method exhibited good accuracy and precision for the detection of DON in wheat samples.

\subsection{DON distribution in wheat milling process}

The results showed that DON was detected in $35 \%$ of all wheat fractions. The DON levels in the wheat milling fractions of the positive samples are shown in Fig. 1, where it is possible to observe the distribution of each positive sample individually. The statistical difference $(P<0.05, P<0.01, P<0.001)$ was observed in almost all positive samples of finished flour compared to milled wheat samples. In two positive samples, the finished flour DON levels were slightly higher than milled wheat, but do not differ significantly. This result may be due the heterogeneity distribution of mycotoxins in wheat fractions, however, factors that cause this variability have yet to be determined (Cheli, Pinotti, Rossi, \& Dell'Orto, 2013).

The bran fraction had the highest mean concentration of DON (2278 $\mu \mathrm{g} \mathrm{kg}^{-1}$ ), followed by milled wheat and finished flour (1895 $\mu \mathrm{g} \mathrm{kg}^{-1}$ and $1305 \mu \mathrm{g} \mathrm{kg}^{-1}$ ). In addition, the highest median and maximum concentration of DON were 2613 and $2931 \mu \mathrm{g} \mathrm{kg}^{-1}$

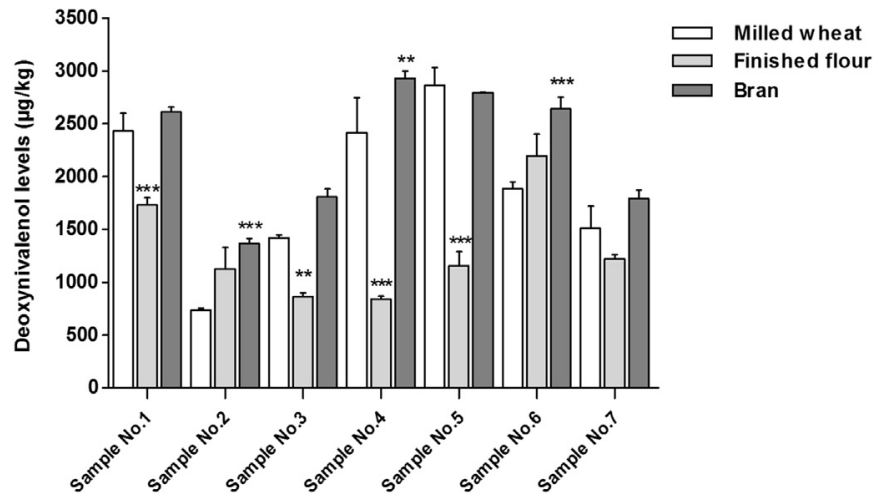

Fig. 1. Deoxynivalenol levels $\left(\mu \mathrm{g} \mathrm{kg}^{-1}\right)$ in the wheat milling fractions of the positive samples. Statistically significance compared with milled wheat ${ }^{* *} P<0.01$, ***P $<0.001$, according to ANOVA and Bonferroni post-test.

for bran, followed by 1887 and $2866 \mu \mathrm{g} \mathrm{kg}^{-1}$ for milled wheat and 1158 and $2195 \mu \mathrm{g} \mathrm{kg}^{-1}$ for finished flour. Therefore, the distribution factor of bran was found to be $120 \%$, in contrast with finished flour (69\%), which demonstrates that DON in this inner fraction was reduced compared to milled wheat (Table 1 ).

The results of the current study are in accordance with the affirmation that mycotoxin contamination may be redistributed and concentrated in certain milling fractions, however, these are not reduced in the milling process (Cheli et al., 2013; Tibola et al., 2015). The cleaning and milling usually performed in naturally Fusariumcontaminated wheat, result in less contaminated fractions intended for human consumption (flour or semolina), while a concentration factor was observed for the fractions mainly intended for animal feed (bran or middlings) (Cheli et al., 2010; Samar, Ferro Fontan, Resnik, Pacin, \& Castillo, 2003; Scott, Kanhere, Dexter, Brennan, \& Trenholm, 1984; Scudamore \& Patel, 2008). Brera et al. (2013) also observed an increase of DON contamination in the foliage waste (about 10 fold) and in the wheat bran fraction (from 5 to 2 fold), which are intended for feed production. It is according to our study, which showed the high contamination of DON in bran compared to milled wheat, indicating a concentration of toxins in the outer part of the kernel. It may be attributed to the fact that bran fractions are obtained by the fine particles created mainly during the milling of the external layers of the kernels (Castells, Marín, Sanchis, \& Ramos, 2008). This affirmation is also true for maize, where Burger, Shephard, Louw, Rheeder, and Gelderblom (2013) found that DON was noticeably concentrated about 3 fold greater in the total hominy feed fraction (germ + milling hominy feed) than in the whole corn.

On the other hand, the significantly lower DON levels in finished flour may be attributed to the potential of the bran layer to behave as a physical barrier preventing the mycelia from penetrating further into the kernel structure (Rios et al., 2009). Similarly to our results, other studies also showed that the DON contamination in finished flour was significantly lower than in milled wheat (Edwards et al., 2011; Tibola et al., 2015; Tibola, Fernandes, \& Guarienti, 2016).

In a study conducted by Tibola et al. (2015) concerning the impact of the milling process on the Fusarium mycotoxin content in artificially contaminated wheat, the authors reported that the milling process cannot be solely used as an effective tool for mycotoxin reduction in the wheat fractions. In this study, in wheat DON levels $>3000 \mu \mathrm{g} \mathrm{kg}{ }^{-1}$, bran presented the higher contamination $(7407 \pm 535 \mu \mathrm{g} \mathrm{kg}-1$ ) compared to milled wheat (5985 $\pm 261 \mu \mathrm{g} \mathrm{kg}^{-1}$ ), with a distribution factor of $123.8 \%$. The finished flour had lower levels $\left(5360 \pm 331 \mu \mathrm{g} \mathrm{kg}^{-1}\right)$ with a distribution factor of $89.5 \%$. Edwards et al. (2011) also showed that the 
Table 1

Deoxynivalenol (DON) levels and distribution factors in wheat milling fractions and wheat-based products.

\begin{tabular}{|c|c|c|c|c|c|}
\hline Fraction & $\begin{array}{l}\text { Number of } \\
\text { sample } \\
\text { positive (\%) }\end{array}$ & $\begin{array}{l}\text { DON level mean of } \\
\text { positive samples } \\
\left(\mu \mathrm{g} \mathrm{kg}^{-1}\right)^{*}\end{array}$ & $\begin{array}{l}\text { Distribution } \\
\text { factor }(\%)\end{array}$ & $\begin{array}{l}\text { Range of DON of } \\
\text { positive samples } \\
\left(\mu \mathrm{g} \mathrm{kg}^{-1}\right)\end{array}$ & $\begin{array}{l}\text { DON median of full data } \\
\text { of positive samples } \\
\left(\mu \mathrm{g} / \mathrm{kg}^{-1}\right)\end{array}$ \\
\hline Milled wheat & $7(35)$ & 1895 & 100 & $737-2866$ & 1887 \\
\hline Finished flour & $7(35)$ & 1305 & 69 & $840-2195$ & 1158 \\
\hline Bran & $7(35)$ & 2278 & 120 & $1366-2931$ & 2613 \\
\hline \multicolumn{6}{|c|}{ Derived Products } \\
\hline Pasta & $<\mathrm{LOD}^{\mathrm{a}}$ & $<$ LOD & - & $<\mathrm{LOD}$ & $<$ LOD \\
\hline Whole bread & $5(17)$ & 491 & - & $165-988$ & 437 \\
\hline Cracker & $3(10)$ & 739 & - & 434-1159 & 624 \\
\hline
\end{tabular}

* Means of wheat fraction are not significantly different to each other $(P<0.05)$, according to ANOVA and Tukey's Multiple Comparison Test.

a $<$ method LOD: $22 \mu \mathrm{g} \mathrm{kg}^{-1}$ and LOQ: $77 \mu \mathrm{g} \mathrm{kg}{ }^{-1}$.

DON level was lower in white flour by an average of 30\% compared to the level in the original cleaned wheat and bran was higher by $282 \%$, while concentration in the germ was approximately equivalent to the cleaned wheat.

According to Brazilian regulations, only 4 (20\%) bran, 3 (15\%) finished flour and $1(5 \%)$ milled wheat samples were above the maximum limits, respectively. However, considering the future Brazilian regulation for DON levels, 7 (35\%) bran, 7 (35\%) finished flour and $6(30 \%)$ milled wheat samples would not be in compliance (ANVISA, 2013). It is in accordance with European regulations for DON levels in cereals products (EC, 2006; 2007).

Taking into account the high presence of contaminated samples, the degree of exposure to chemical compounds is one of the most important parameters in the evaluation of risks to consumers (Martins et al., 2012; Moreno et al., 2009). Table 2 presents the calculations of APDI and MPDI for DON in wheat milling fractions and wheat-based products, according to data from the IBGE (2011). This data shows that the finished flour is the most consumed wheat product in Southern Brazil, where daily intake levels are $32 \mathrm{~g} /$ person/day. In our study, the finished flour (mean: $457 \mu \mathrm{g} \mathrm{kg}^{-1}$ and 90th percentile: $1681 \mu \mathrm{g} \mathrm{kg}^{-1}$ ) was the fraction that most contributed to the intake of DON in Southern Brazil (APDI: $243.7 \mathrm{ng} \mathrm{kg}^{-1}$ body weight day $^{-1}$ and MPDI: $896.5 \mathrm{ng} \mathrm{kg}^{-1}$ body weight day $^{-1}$ ), representing $24.4 \%$ and $89.6 \%$ of PMTDI ( $1 \mu \mathrm{g} \mathrm{kg}^{-1}$ body weight day $\left.{ }^{-1}\right)$, respectively.

\subsection{DON levels in wheat-based products}

From the wheat-based products analyzed, 17\% of whole bread and $10 \%$ of salted cracker products were DON contaminated, with a median of $437 \mu \mathrm{g} \mathrm{kg}-1$ and $624 \mu \mathrm{g} \mathrm{kg}^{-1}$ and a maximum concentration of $988 \mu \mathrm{g} \mathrm{kg}^{-1}$ and $1159 \mu \mathrm{g} \mathrm{kg}^{-1}$ of the positive samples, respectively (Table 1 ).

The wheat-based products such as pasta, bread and crackers did comply with current Brazilian regulations (ANVISA, 2011). However, considering the future Brazilian regulation for DON levels, set at $750 \mu \mathrm{g} \mathrm{kg}^{-1}$, one sample of each wheat product (bread and cracker) would not be in compliance (ANVISA, 2013). In addition, according to European regulation for DON levels, set at $500 \mu \mathrm{g} \mathrm{kg}-1$, one and two samples of bread and cracker were above the maximum limit, respectively (EC, 2006; 2007).

In contrast, other studies showed higher DON level contamination in wheat-based products. Samples of cracker type biscuits from Southern Brazil were analyzed and 78\% samples presented DON levels ranging from 377 to $5295 \mu \mathrm{g} \mathrm{kg}^{-1}$ and approximately $22 \%$ were contaminated at levels higher that those allowed by regulation (Souza, Caldas, Primel, \& Furlong, 2015). In Valencia (Spain), the occurrence of DON and T-2 toxin in bread was $28.0 \%$ and $2.6 \%$, respectively, whereas in pasta, the occurrence of both mycotoxins was higher, varying from 9.3 to $62.7 \%$. The mean content of DON (42.5 $\mu \mathrm{g} \mathrm{kg}^{-1}$ ) in bread was lower than the content of T-2 toxin $\left(68.4 \mu \mathrm{g} \mathrm{kg}^{-1}\right)$, while in pasta the content of DON $\left(137.1 \mu \mathrm{g} \mathrm{kg}^{-1}\right)$ was superior (González-Osnaya, Cortés, Soriano Moltó, \& Mañes, 2011).

According to data from the Household Budget Survey 2008/2009 (IBGE, 2011), the wheat-based products analyzed in our study showed that the maximum concentration (MPDI) for DON was $8.6 \mathrm{ng} \mathrm{kg} \mathrm{kg}^{-1}$ body weight day-1 and $30 \mathrm{ng} \mathrm{kg} \mathrm{kg}^{-1}$ body weight day $^{-1}$. This represents $0.9 \%$ and $3.0 \%$ of PMTDI in whole bread and salted crackers, respectively (Table 2). Similarly,

Table 2

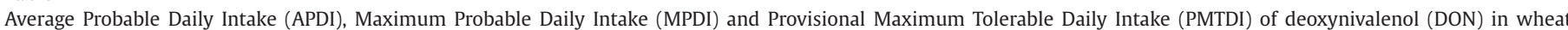
milling fractions and wheat-based products.

\begin{tabular}{|c|c|c|c|c|c|c|c|}
\hline \multirow[t]{3}{*}{ Fraction } & \multicolumn{2}{|c|}{ DON $\left(\mu \mathrm{g} \mathrm{kg}^{-1}\right)$} & \multirow{3}{*}{$\begin{array}{l}\text { Consumption } \\
\left(\mathrm{g} \text { person day }{ }^{-1}\right)^{*}\end{array}$} & APDI & \multirow{2}{*}{$\begin{array}{l}\text { MPDI } \\
\frac{\text { y weight } \text { day }^{-1} \text { ) }}{\text { wat }}\end{array}$} & \multicolumn{2}{|c|}{ PMTDI**(\%) } \\
\hline & \multirow[b]{2}{*}{ Mean } & \multirow[b]{2}{*}{90 th Percentile } & & $\overline{\left(\mathrm{ng} \mathrm{kg}^{-1}\right.}$ body weight day $\left.{ }^{-1}\right)$ & & \multirow[b]{2}{*}{ Mean } & \multirow[b]{2}{*}{90 th Percentile } \\
\hline & & & & Mean & 90 th Percentile & & \\
\hline Milled wheat ${ }^{\mathrm{a}}$ & 663 & 2431 & 0.6 & 6.6 & 24.3 & 0.7 & 2.4 \\
\hline Finished flour & 457 & 1681 & 32 & 243.7 & 896.5 & 24.4 & 89.6 \\
\hline $\operatorname{Bran}^{\mathrm{b}}$ & 797 & 2781 & 0.4 & 5.3 & 18.5 & 0.5 & 1.8 \\
\hline \multicolumn{8}{|c|}{ Derived products } \\
\hline Pasta & $<\mathrm{LOD}^{\mathrm{C}}$ & $<$ LOD & 8.4 & $<$ LOD & $<$ LOD & $<\mathrm{LOD}$ & $<$ LOD \\
\hline Whole bread & 82 & 430 & 1.2 & 1.6 & 8.6 & 0.2 & 0.9 \\
\hline Cracker & 74 & 390 & 4.6 & 5.7 & 30 & 0.6 & 3.0 \\
\hline
\end{tabular}

* Data of Brazilian Institute of Geography and Statistics (IBGE, 2011), performed according to Household food consumption 2008/2009 of Southern Brazil.

** Body weight: $60 \mathrm{~kg}$.

a Other cereals.

b Other wheat flour.

c $<$ method LOD: $22 \mu \mathrm{g} \mathrm{kg}-1$ and LOQ: $77 \mu \mathrm{g} \mathrm{kg}{ }^{-1}$. 
in a study conducted by Pacin et al. (2010), a low exposure was estimated due to low DON contamination: French bread median was $35.5 \mu \mathrm{g} \mathrm{kg}^{-1}$ and Vienna bread $22.0 \mu \mathrm{g} \mathrm{kg}^{-1}$ (the highest percentage of the tolerable daily intake was $6.54 \%$ and the lowest $0.45 \%$, respectively).

In a study performed by González-Osnaya et al., (2011) in Valencia (Spain), the estimated daily intake of DON and T-2 toxin from the consumption of pasta and bread represents $8.4 \%$ and $0.2 \%$ of the tolerable daily intake, respectively. In the Indian region, the results suggest that the average estimated daily intake of DON in wheat products was found to be three times higher than the PMTDI proposed by JECFA, suggesting that chronic exposure to DON by the Indian population could be one of the factors contributing to gastrointestinal disorders in the Uttar Pradesh region (Mishra et al., 2013).

On the other hand, the average intake of the inhabitants of Londrina City in a northern Paraná State (Brazil) was $0.79 \mu \mathrm{g} \mathrm{kg}^{-1}$ body weight for bread and $0.35 \mu \mathrm{g} \mathrm{kg}^{-1}$ body weight for pasta. The total estimated daily intake was $1.13 \mu \mathrm{g} \mathrm{kg}^{-1}$, which is above the PTDMI of $1 \mu \mathrm{g} \mathrm{kg}^{-1}$ body weight (Santos et al., 2013).

The DON intake values found in wheat milling fractions and wheat-based products are less than the tolerable intake $1 \mu \mathrm{g} \mathrm{kg}^{-1}$ body weight day $^{-1}$ for DON proposed by JECFA (2011). The PMTDI for DON was higher in the finished flour fraction representing $89.6 \%$, which complies with the current regulation. However, the high frequency of contamination found in wheat milling fractions and the permanency in these toxins in wheat-based products demonstrated the need for monitoring of the foods through current regulations, with the aim to minimize health risks due to DON exposure.

\section{Conclusion}

The bran fraction had the highest DON levels and distribution factors, due to the milling of the external layers, where there was a higher DON concentration. The finished flour had poor transfer of DON for this fraction, resulting in lower DON levels compared to milled wheat. Despite this, it was the fraction that most contributed to the daily intake of DON in Southern Brazil.

Taking into account the future Brazilian regulation for DON levels, a percentage of $35 \%$ of bran samples (DON levels higher fraction) would not be in compliance (ANVISA, 2013). The milling process may not reduce the level of DON in wheat fraction and the concern is that this toxin tends to be concentrated in outer fractions commonly used as animal feed, which presents a greater concern, as there are no regulation limits established for animal feed in Brazil.

From wheat-based products, one sample of each wheat product (bread and cracker) would not be in compliance considering the future Brazilian regulations for DON levels.

The PMDTI of all samples analyzed did comply with current regulations. However, it is important emphasize that the PMTDI currently set by JECFA also includes the acetylated forms, which were not studied. Moreover, the risks due to DON higher exposure should be taking into account, even though the daily exposure level comply with regulations, due to the high consumption of this cereal.

\section{Acknowledgments}

The authors thank the Brazilian Agricultural Research Corporation (Embrapa, Passo Fundo, Brazil) for providing milled wheat samples. This study was supported by the National Council for Scientific and Technological Development (CNPq) [grant number Call MCTI/CNPq/ANVISA No: 23/2012].

\section{References}

AACC International (2000). Approved methods of analysis. Experimental milling: Introduction, equipment, sample preparation, and tempering. Approved November 8 , 2000 (10th ed.). St. Paul: AACC International (Method 26-10A).

ANVISA (2011). Agência Nacional de Vigilância Sanitária. Dispõe sobre limites máximos tolerados (LMT) para micotoxinas em alimentos. Resolução-RDC no. 7, de 18 de fevereiro de 2011. Brasília, DF: ANVISA Available in http://www.brasilsus.com. br/legislacoes/anvisa/107378-7.html Acessed 15.01.15.

ANVISA (2013). Agência Nacional de Vigilância Sanitária. Prorrogação para $1^{\circ}$ de janeiro de 2017 o prazo para adequação estabelecidos nos artigos 11 e 12 e respectivos anexos III e IV da Resolução - RDC no. 7, de 18 de fevereiro de 2011, que dispõe sobre limites máximos tolerados (LMT) para micotoxinas em alimentos. Resolução no. 59 publicada em 30/12/2013. Brasília, DF: ANVISA Available in http://portal. anvisa.gov.br/wps/wcm/connect/40fd6c004337b6ccaf51af1e82c52611/. Acessed 15.01.15.

Bensassi, F., Zaied, C., Abid, S., Hajlaoui, M. R., \& Bacha, H. (2010). Occurrence of deoxynivalenol in durum wheat in Tunisia. Food Control, 21, 281-285.

Brera, C., Peduto, A., Debegnach, F., Pannunzi, E., Prantera, E., Gregori, E., et al. (2013). Study of the influence of the milling process on the distribution of deoxynivalenol content from the caryopsis to cooked pasta. Food Control, 32, 309312.

Burger, H. M., Shephard, G. S., Louw, W., Rheeder, J. P., \& Gelderblom, W. C. A. (2013). The mycotoxin distribution in maize milling fractions under experimental conditions. International Journal of Food Microbiology, 165, 57-64.

Castells, M., Marín, S., Sanchis, V., \& Ramos, A. J. (2008). Distribution of fumonisins and aflatoxins in corn fractions during industrial cornflake processing. International Journal of Food Microbiology, 123, 81-87.

Cheli, F., Campagnoli, A., Ventura, V., Brera, C., Berdini, C., Palmaccio, E., et al. (2010). Effects of industrial processing on the distributions of deoxynivalenol, cadmium and lead in durum wheat milling fractions. LWT - Food Science and Technology, 43, 1050-1057.

Cheli, F., Pinotti, L., Rossi, L., \& Dell'Orto, V. (2013). Effect of milling procedures on mycotoxin distribution in wheat fractions: a review. LWT- Food Science and Technology, 54, 307-314.

Edwards, S. G., Dickin, E. T., MacDonald, S., Buttler, D., Hazel, C. M., Patel, S., et al. (2011). Distribution of Fusarium mycotoxins in UK wheat mill fractions. Food Additives and Contaminants, 28, 1694-1704.

European Commission Regulation (2006). No 1881/2006 of 19 December 2006 setting maximum levels for certain contaminants in foodstuffs. Official Journal of the European Union $L, 364,5$.

European Commission Regulation (2007). No 1126/2007 of 28 September 2007 amending Regulation No 1881/2006 setting maximum levels for certain contaminants in foodstuffs as regards Fusarium toxins in maize and maize products. Official Journal of the European Union L, 255, 14.

Giménez, I., Herrera, M., Escobar, J., Ferruz, E., Lorán, S., Herrera, A., et al. (2013). Distribution of deoxynivalenol and zearalenone in milled germ during wheat milling and analysis of toxin levels in wheat germ and wheat germ oil. Food Control, 34, 268-273.

González-Osnaya, L., Cortés, C., Soriano, J. M., Moltó, J. C., \& Mañes, J. (2011). Occurrence of deoxynivalenol and T-2 toxin in bread and pasta commercialised in Spain. Food Chemistry, 124, 156-161.

Herrman, J. L., \& Yunes, M. (1999). Background to the ADI/TDI/PTWI. Regulatory Toxicology and Pharmacology, 30, S109-S113.

IBGE (2011). Pesquisa de Orçamentos Familiares - POF 2008-2009. Aquisição Alimentar Domiciliar per capita - Brasil e Grandes Regiões. Instituto Brasileiro de Geografia e Estatística Available in http://www.ibge.gov.br/home/estatistica/populacao/ condicaodevida/pof/2002aquisicao/default.shtm. Acessed 24.06.15.

JECFA (2011). Evaluation of certain contaminants in food: Seventy-second report of the Joint FAO/WHO Expert Committee on Food Additives p. 959 WHO Technical Report Series. Joint Expert Committee on Food Additives.

Martins, F. A., Ferreira, F. M. D., Ferreira, F. D., Bando, E., Nerilo, S. B., Hirooka, E. Y., et al. (2012). Daily intake estimates of fumonisins in corn-based food products in the population of Parana, Brazil. Food Control, 26, 614-618.

McMullen, M., Jones, R., \& Gallenberg, D. (1997). Scab of wheat and barley: a reemerging disease of devastating impact. Plant Disease, 81, 1340-1348.

Mishra, S., Ansari, K. M., Dwivedi, P. D., Pandey, H. P., \& Das, M. (2013). Occurrence of deoxynivalenol in cereals and exposure risk assessment in Indian population. Food Control, 30, 549-555.

Moreno, E. C., Garcia, G. T., Ono, M. A., Vizoni, E., Kawamura, O., Hirooka, E. Y., et al. (2009). Co-occurrence of mycotoxins in corn samples from the Northern region of Paraná State, Brazil. Food Chemistry, 116, 220-226.

Pacin, A., Ciancio Bovier, E., Cano, G., Taglieri, D., \& Hernandez Pezzani, C. (2010). Effect of the bread making process on wheat flour contaminated by deoxynivalenol and exposure estimate. Food Control, 21, 492-495.

Parry, D. W., Jenkinson, P., \& Mcleod, L. (1995). Fusarium ear blight (scab) in small grain cereals, a review. Plant Pathology, 44, 207-238.

Pestka, J. J. (2007). Deoxynivalenol: toxicity, mechanisms and health risks. In D. P. Morgavi, \& R. T. Riley (Eds.): 137, Fusarium and their toxins: Mycology, occurrence, toxicity, control and economic impact. Animal feed science and technology (pp. 283-298).

Pinson-Gadais, L., Barreau, C., Chaurand, M., Gregoire, S., Monmarson, M., \& RichardForget, F. (2007). Distribution of toxigenic Fusarium spp. and mycotoxin production in milling fractions of durum wheat. Food Additives $\mathcal{E}$ Contaminants, 24, 53-62. 
Rios, G., Zakhia-Rozis, N., Chaurand, M., Richard-Forget, F., Samson, M. F., Abecassis, J., et al. (2009). Impact of durum wheat milling on deoxynivalenol distribution in the outcoming fractions. Food Additives and Contaminants Part A Chemistry Analysis Control Exposure \& Risk Assessment, 26, 487-495.

Rodrigues, I., \& Naehrer, K. (2012). A three-year survey on the worldwide occurrence of mycotoxins in feedstuffs and feed. Toxins, 4, 663-675.

Rotter, B. A., Prelusky, D. B., \& Pestka, J. J. (1996). Invited review: toxicology of deoxynivalenol (vomitoxin). Journal of Toxicology and Environmental Health Part A, $48,1-34$.

Samar, M. M., Ferro Fontan, C. Resnik, S. L. Pacin, A. M., \& Castillo, M. D. (2003) Distribution of deoxynivalenol in wheat, wheat flour, bran and gluten, and variability associated with test procedure. Journal of AOAC International, 86, 551556.

Santos, J. S., Souza, T. M., Ono, E. Y. S., Hashimoto, E. H., Bassoi, M. C., Miranda, M. Z., et al. (2013). Natural occurrence of deoxynivalenol in wheat from Paraná State, Brazil and estimated daily intake by wheat products. Food Chemistry, 138, 9095.

Savi, G. D., Piacentini, K. C., Souza, S. R., Costa, M. E. B., Santos, C. M. R., \& Scussel, V. M. (2015). Efficacy of zinc compounds in controlling Fusarium head blight and deoxynivalenol formation in wheat (Triticum aestivum L.). International Journal of Food Microbiology, 205, 98-104.

Savi, G. D., Piacentini, K. C., Tibola, C. S., \& Scussel, V. M. (2014). Mycoflora and deoxynivalenol in whole wheat grains (Triticum aestivum L.) from Southern Brazil. Food Additives \& Contaminants: Part B, 7, 232-237.

Scott, P. M., Kanhere, S. R., Dexter, J. E., Brennan, P. W., \& Trenholm, H. L. (1984). Distribution of DON during the milling of naturally contaminated hard red spring wheat and its fate in baked products. Food Additives and Contaminants, 12, 313323 .
Scudamore, K. A., \& Patel, S. (2008). The fate of deoxynivalenol and fumonisins in wheat and maize during commercial breakfast cereal production. World Mycotoxin Journal, 1, 437-448.

Scussel, V. M., Beber, M., \& Tonon, K. M. (2011). Efeitos da infecção por Fusarium/Giberella na qualidade e segurança de grãos, farinhas e produtos derivados. In E. M. Reis (Org. ) (Ed.), Seminário sobre Giberella em cereais de inverno (pp. 131-175) 1ed. Passo Fundo: Berthier.

Souza, T. D., Caldas, S. S., Primel, E. G., \& Furlong, E. B. (2015). Exposure to deoxynivalenol, HT-2 and T-2 toxins by consumption of wheat-based product in southern Brazil. Food Control, 50, 789-793.

Tibola, C. S., Fernandes, J. M. C., \& Guarienti, E. M. (2016). Effect of cleaning, sorting and milling processes in wheat mycotoxin content. Food Control, 60, 174-179.

Tibola, C. S., Fernandes, J. M. C., Guarienti, E. M., \& Nicolau, M. (2015). Distribution of Fusarium mycotoxins in wheat milling process. Food Control, 53, 91-95.

Vicam (2013). Deoxynivalenol (DON) testing solutions. DON test HPLC Available in http://vicam.com/don-test-kits. Acessed 16.02.15.

Visconti, A., Haidukowski, E. M., Pascale, M., \& Silvestri, M. (2004). Reduction of deoxynivalenol during durum wheat processing and spaghetti cooking. Toxicology Letters, 153, 181-189.

Wijnands, L. M., \& Van Leusden, F. M. (2000). An overview of adverse health effects caused by mycotoxins and biossays for their detection RIVM report 257852004 Bilthoven.

Zhang, H., \& Wang, B. (2014). Fate of deoxynivalenol and deoxynivalenol-3-glucoside during wheat milling and Chinese steamed bread processing. Food Control, 44, 86-91.

Zimmer, I., Usleber, E., Klaffke, H., Weber, R., Majerus, P., Otteneder, H., et al. (2008). Fumonisin intake of the German consumer. Mycotoxin Research, 24, 40- 